\title{
Race and the Working-Class Past in the United States: Multiple Identities and the Future of Labor History
}

\author{
DAVID ROEDIGER
}

In concluding his 1935 masterpiece, Black Reconstruction in America, W.E.B. DuBois observed:

The most magnificent drama in the last thousand years of human history is the transportation of ten million human beings out of the dark beauty of their mother continent into the new-found Eldorado of the West. They descended into Hell; and in the third century they arose from the dead, in the finest effort to achieve democracy for the working millions which this world had ever seen. It [post-Civil War Reconstruction in the U.S.] was a tragedy that beggared the Greek; it was an upheaval of humanity like the Reformation and the French Revolution. Yet we are blind and led by the blind. We discern in it no part of our labour movement $[\ldots]^{1}$

Since DuBois wrote those lines historians have made substantial strides toward portraying the drama of African-American labor history, but have only begun to appreciate how a consideration of race might change the way the broader drama of labor in the U.S. past it itself plotted. This article argues that we may now at last be on the verge of a redramatization of U.S. labor history which moves race from the margins to the center of the story and which fully historicizes and problematizes the racial consciousness of white workers, as DuBois does from the earliest pages of Black Reconstruction.

However, in advancing this hopeful argument, I would stress that the grounds for hope have been present before, but not fully realized. Likewise deserving emphasis are the tremendous stakes involved in a reconceptualization of race and class in the past of U.S. labor. DuBois' framing of the issue in terms of drama captures those stakes strikingly. The ability of labor historians to cast their research in terms of dramatic issues like emancipation and independence, and to penetrate the ways in which workers conceptualized those issues, depends in large measure on extending to the discussion of race and class the same sort of tough-minded analysis which has matured more quickly where the study of gender and class is concerned. The first section of this study surveys recent historiography to make a case for cautious optimism regarding the future of a labor history which fully incorporates race and gender. The balance of the

1 W. E. B. DuBois, Black Reconstruction in America, 1860-1880 (New York, 1962, originally 1935), p. 727; ef. David Montgomery, "The Conventional Wisdom", Labor History, 13 (Winter, 1972), p. 134.

International Review of Social History 38 (1993), Supplement, pp. 127-143 
essay makes concrete the stakes involved in reconceptualizing race in the working class past by concretely examining three small but significant dramas.

The tardiness of U.S. labor historians in making the study of slavery and race central to their work is as ironic as it is regrettable. The very project of a "new labor history" initially gained its appreciation for the fact that masses of working people make their own history not so much through witnessing significant trade union insurgencies as through the example of the Black freedom movement. The leading figures in early attempts to rewrite working class history were profoundly influenced by DuBois and, to a lesser extent, by the Black Trinidadian historian C.L.R. James. Herbert Gutman set out a research agenda which, as Ira Berlin has written, made "study of the Afro-American family [ . . . ] not a detour on the road to a history of the American working class, but the center lane on the main highway". 2 Such scholars at Gutman, Harold Baron, Paul Worthman and James Green produced pathbreaking analyses of race and labor. Above all, Alexander Saxton published The Indispensable Enemy: Labor and the Anti-Chinese Movement in California in $1971 .{ }^{3}$ Saxton's work, itself indispensable and unsurpassed, fully raised the question of the impact of white racial identity on unions and on white workers themselves at that early date.

Nonetheless, scholarship on race and labor failed to flower. Saxton and George Rawick did not come to be considered central figures in the new labor history as David Brody, David Montgomery and Gutman did. Fascinating studies of race and white workers, such as those by Mary Ellen Freifeld and Barry Goldberg, remained unpublished and underappreciated. Eric Foner, Sean Wilentz and Mongomery brilliantly and convincingly restored the centrality of the sectional controversy, the Civil War

2 See Berlin's introduction to Herbert Gutman, Power and Culture: Essays on the American Working Class(New York, 1987), p. 46; the interviews with Mongomery and Gutman in MARHO, ed., Visions of History (New York, 1983) and "Dave Roediger Interviews George Rawick", in Don Fitz and David Roediger, eds., Within the Shell of the Old (Chicago, 1990). As David Brody observes, however, Gutman took a range of positions on the placing of slavery and race within working-class history. See Brody, "On Creating a New Synthesis of American Labor History", in J. Carroll Moody and Alice Kessler-Harris, eds., Perspectives on American Labor History: The Problems of Synthesis (Dekalb, IL, 1989), p. 216 n. 9 and Mimi Rosenberg, "An Unpublished Interview with Herbert Gutman on United States Labor History", Socialism and Democracy, 10 (Spring-Summer, 1990), p. 58.

${ }^{3}$ Saxton, The Indispersable Enemy: Labor and the Anti-Chinese Movement in Californio (Berkeley, 1971); Baron, "The Demand for Black Labor: Historical Notes on the Political Economy of Racism", in James Green, ed., Workers' Struggles, Past and Present (Philadelphia, 1983); Paul Worthman, "Black Labor and Labor Unions in Birmingham, Alabama, 1897-1904"' in Milton Cantor, ed., Black Labor in America (Westport, CT, 1969); Green, "The Brotherhood of Timber Workers, 1910-1913", Past and Present, 60 (August, 1973), pp. 161-200; Gutman, "The Negro and the United Mine Workers of America: The Career and Letters of Richard L. Davis and Something of Their Meaning, 1890-1900" in 
and Reconstruction to working-class history, but they did so largely without the same emphasis DuBois placed on the self-activity of black workers and the white racial identity of white workers. ${ }^{4}$

Herbert Hill may be partly correct in attributing the new labor history's failure to engage fully the questions of racial identity and racism to an excessively zealous search for a usable and inspiring past. ${ }^{5}$ However, other factors also mattered greatly. The nearly total isolation of communist historians from the new labor history deprived younger scholars of associations with Philip S. Foner and Herbert Aptheker, two of the most knowledgeable students of race, anti-racism and labor. ${ }^{6}$ The strong influence of Eugene Genovese's weighty studies of slavery as a precapitalist political economy tended to isolate the history of slavery from the history of wage labour. ${ }^{7}$ Moreover, the very strength of the new history's emphasis on daily life made it less-than-quick to understand the symbolic and political importance of whiteness even to white workers who did not regularly encounter workers of different racial identities. ${ }^{8}$

Several recent developments open the possibility that the new labor history will at long last realize its early promise with regard to providing a full consideration of race and a critique of working-class whiteness. The novelist and critic Toni Morrison has recently observed that studies of

Julius Jacobson, ed., The Negro and the American Labor Movement (Garden City, NY, 1968), pp. 49-127.

4 Barry H. Goldberg, "Beyond Free Labor: Labor, Socialism and the Idea of Wage Slavery, 1890-1920" (Ph.D. diss., Columbia University, 1979) and Mary Ellen Freifeld, "The Emergence of the American Working Classes: The Roots of Division, 1865-1885" (Ph.D. diss., New York University, 1980); Foner, Free Soil, Free Labor, Free Men: The Ideology of the Republican Party before the Civil War (New York, 1970); Foner, Reconstruction: America's Unfinished Revolution, 1863-1877 (New York, 1988); Mongomery, Beyond Equality: Labor and the Radical Republicans, 1862-1872 (New York, 1967); Wilentz, "The Rise of the American Working Class, 1776-1877: A Survey" in Moody and Kessler-Harris, eds., American Labor History, pp. 83-151.

${ }^{3}$ See, for example, Hill, "Mythmaking as Labor History: Herbert Gutman and the United Mine Workers of America", International Journal of Politics, Culture and Society, 2 (Winter, 1988), pp. 132-98. My own fuller refiections on race and the new labor history are found in "Labor in White Skin: Race and Working Class History" in Mike Davis and Michael Sprinker, eds., Reshaping the U.S. Left (London and New York, 1988), pp. 287-308.

6 See Philip S. Foner, Organized Labor and the Black Worker, 1819-1973 (New York, 1974); Bettina Aptheker, ed., The Unfolding Drama: Studies in United States History by Herbert Aptheker (New York, 1979); Melvyn Dubofsky, "Give Us That Old Time Labor History: Philip S. Foner and the American Worker", Labor History, 26 (1985), pp. 118-37.

"Brody, "Synthesis", in Moody and Kessler-Harris, eds., American Labor History, p. 216 n. 9 and Roediger. "Precapitalism in One Confederacy: Genovese and the Politics of History", New Politics, 13 (Summer, 1991), pp. 90-95. Note, however, that Genovese's practice in comparing labor under slavery and under the wage system has been more supple than his theory. See esp. Roll, Jordan, Roll: The World the Slaves Made (New York, 1976), esp. pp. 285-324.

"Rosenberg, "Unpublished Interview", p. 58. 
gender relations and identity have cleared the ground for the reconsideration of racial identity within cultural studies generally. ${ }^{9}$ Her point applies with specific force to labor history. In the last decade, gendered studies of the working-class past have proven far and away the most dramatic contributions to labor history. Studying not only women workers but the masculinity of male craft workers and trade unionists, historians have reinvigorated scholarship on unorganized workers, pioneered in sophisticated research on labor in the service industries, and convincingly connected the work experience with ideology, family, consumption, and leisure. ${ }^{10}$ Many of these historians, including Joanne Meyerowitz, Evelyn Nakono Glenn, Nancy Hewitt, Dolores Janiewski, Vicki Ruiz, Dana Frank, Patricia Cooper and Tera Hunter, have been enormously attentive to the dynamics of race as well as to class and gender. ${ }^{11}$

But even when they have not discussed race extensively, historians of labor and gender have made a decisive contribution to the study of race and class. They have demonstrated, particularly in the recent work of Joy Parr, Elizabeth Faue, and Jeanne Boydston, that the consideration of class and gender is not a zero-sum game in which an increasing emphasis on

9 Morrison, "Unspeakable Things Unspoken: The Afro-American Presence in American Literature," Michigan Quarterly Review, 28 (Winter, 1989), esp. pp. 2-3 and 38.

${ }^{10}$ A quite incomplete list of major recent works would feature Christine Stansell, City of Women: Sex and Class in New York, $1789-1860$ (New York, 1986); Susan Porter Benson, Counter Cultures: Saleswomen, Managers and Customers in American Department Stores, 1890-1910 (Urbana, 1986); Barbara Melosh, The Physician's Hand: Work Culture and Conflict in American Nursing (Philadelphia, 1982); Mary Blewett, Men, Women and Work: Class, Gender and Protest in the New England Shoe Industry, 1780-1910 (Urbana, 1988); Alice Kessler-Harris, A Woman's Wage: Historical Meanings and Social Consequences (Lexington, KY, 1990); Ava Baron, ed., Work Engendered: Toward a New History of Men, Women and Work (Ithaca, NY, 1991); Jacqueline Dowd Hall, "Disorderly Women: Gender and Labor Militancy in the Appalachian South' in Ellen Carol DuBois and Vicki L. Ruiz, Unequal Sisters: A Multicultural Reader in U.S. Women's Hisrory (New York and London, 1990), pp. 298-321. Kathy Peiss, Cheop Amusements: Working Women and Leisure in Turn-of-theCentury New York (Philadelphia, 1986). See also Lois Helmbold and Ann Schofield, "Women's Labor History, 1790-1945", Reviews in American Labor History, 17 (December, 1989 ) and notes 25 and 16 below.

${ }^{11}$ Glenn, "The Dialectics of Wage Work: Japanese-American Women and Domestic Service, 1905-1940" in DuBois and Ruiz, eds., Unequal Sisters, pp. 345-72; Joanne J. Meyerowitz, Women Adrift: Independent Wage Earners in Chicago, 1880-1930 (Chicago and London, 1988); Dana Frank, "Race, Class and the Politics of Consumption: Race Relations and the Seattle Labor Movement, 1915-1929". (unpublished paper delivered at Organization of American Historians meeting, 1991); essays by Hewitt and Janiewski in Baron, ed., Work Engendered; Janiewski, Sisterhood Denied: Race, Gender, and Class in a New South Community (Philadelphia, 1985); Vicki Ruiz, Cannery Women, Cannery Lives: Mexican Women, Unionization and the California Food Processing Industry, 1930-1950 (Albuquerque, 1987); Patricia A. Cooper, Once a Cigarmaker. Men, Women, and Work Culture in American Cigar Factories, 1900-1919 (Urbana and Chicago, 1987). I particularly thank Tera Hunter for sharing a manuscript version of her powerful Contesting the New South: The Politics and Culture of Wage Household Labor in Allanta, 1961-1920 with me. 
one "variable" leads inexorably to a diminished emphasis on the other. ${ }^{12}$ Instead class identity and gender identity are so thoroughly interpenetrating that intellectual excitement and understanding come precisely when both are stressed. This example has strongly encouraged a moving away from dead end debates about whether to give priority to race or class identity in the study of labor as well, and a moving toward the difficult, rewarding task of showing how racial identity and class identity have shaped each other. Moreover in giving attention to masculine as well as feminine gender identity, recent labor history has set a vital precedent which can lead to full interrogation of the racial identity of the dominant racial group as well as of the subordinate ones.

The recent outpouring of work on African-American, Asian-American and Latino labor history further signals the possibility that a consideration of race will structure, and not just appear episodically in, new attempts at synthesis in U.S. working-class history. Workers of color occupy prominent places in recent studies of race relations in the unions and among the working class generally, with major contributions made by such scholars as Iver Bernstein, Bruce Nelson, Barbara Griffith, Rich Halpern, Wayne Durrill, Peter Rachleff, Nelson Lichtenstein, Robert Korstad, Robert Norrell, Eric Arnesen, Michael Honey, Roger Horowitz and Nancy Quam Wickham. ${ }^{13}$ Much of the finest work in labor history in the past five years has been the result of the partial democratization of the universities. Ronald Takaki, Earl Lewis, Joe William Trotter, Vicki Ruiz, Robin D.G. Kelley and Tera Hunter have written powerful studies which open the possibility that the best of labor history research in the near future will in

12 Joy Parr, The Gender of Breadivinners: Women, Men and Change in Two Industrial Towns, 1888-1950 (Toronto, 1990); Faue, Community of Suffering and Struggle: Women, Men, and the Labor Movement in Minneapolis, 1915-1845 (Chapel Hill, 1991). Boydston, Home and Work: Housework, Wages, and the Ideology of Labor in the Early Republic (New York and Oxford, 1990).

${ }^{13}$ Again, the list is quite incomplete, but see Rick Halpern, "Race, Ethnicity and the Union in the Chicago Stockyards, 1917-1922"', International Review of Social History, 37 (1992), pp. 25-58; Iver Bernstein, The New York City Draft Riots: Their Significance for American Society and Politics in the Age of the Civil Way (New York, 1990); Griffith, The Crisis of American Labor: Operation Dixie and the Defeat of the ClO (Philadelphia, 1988); Eric Arnesen, Waterfront Workers of New Orleans, Race, Class and Politics (New York, 1990); Arnesen, "Rethinking the historical Relationship between Black Workers and the Labor Movement", forthcoming in Radical History Review (1993); Wayne Durrill, War of Another Kind: A Southern Community in the Great Rebellion (New York and Oxford, 1990); Nancy Quam Wickham, "Who Controls the Hiring Hall? The Struggle for Job Control in the ILWU During World War II" and Bruce Nelson, "Class and Race in the Crescent City: The ILWU, from San Francisco to New Orleans", both in Steven Rosswurn, ed., The ClO's Left-Led Unions (New Brunswick, NJ, 1992), pp. 19-68; the essays in Robert Zieger, ed., Organized Labor in the Twentieth Century South (Knoxville, 1991); Leon Fink and Brian Greenberg, Upheaval in the Quiet Zone: A History of Hospital Workers' Union Local 119 (Urbana, IL, 1989); and, above all, Peter Rachleff, Black Labor in the South: Richmond, Virginia, 18651890 (Philadelphia, 1984). 
large part be by, as well as about, "nonwhite" Americans. Indeed, the very recent scholarship by Kelley and Hunter comes closer to making real the new labor history's vision of connecting work, community, daily life, consciousness, and resistance than do any other American studies written during the last decade. ${ }^{14}$

Finally, during a period in which every major election has provided reminders that finding a usable past necessitates confronting the issue of white racial identity, scholars have succeeded in raising the questions of when, why, and with what results so-called "white people" have come to identify themselves as white. Making whiteness, rather than simply white racism, the focus of study has had the effect of throwing into sharp relief the impact which the dominant racial identity in the U.S. has had not only on the treatment of racial "others" but also on the ways that whites think of themselves, of power, of pleasure, and of gender. Labor historians cannot claim to have pioneered in this problematizing of the notion of whiteness. That honor belongs to figures in literary and cultural studies, including bell hooks, Coco Fusco, Toni Morrison, and a host of others who sometimes write with rather more postmodernist jargon than we would prefer. ${ }^{13}$ But labor historians do have a distinctive and critical contribution to make by historicizing discussions of whiteness and by showing the ways that what DuBois brilliantly termed the "public and psychological wages" of white racial identity varied over time, place, and class location. Moreover, insofar as the new labor history has consistently stressed the role of workers as creators of their own culture, it is particularly well positioned to understand that white identity is not merely the product of elites or of discourses. If some of the most deeply historical work on whiteness and class continues to emerge from English and political science departments, labor historians can at least point with pride to the fact that one of their number, Alexander Saxton, has written the most sweeping and provocative account yet of the pivotal role of

14 Takaki, Pau Nana: Plantation Life and Labor in Hawaii, 1835-1920 (Honolulu, 1983); Lewis, In Their Own Interest: Race, Class and Power in Twentieth Century Norfolk, Virginia (Berkeley, 1991); Trotter, Black Milwaukee: The Making of an Industrial Proletariat, 1914 45 (Urbana, IL, 1984) and Class, Coal, and Color: Blacks in Southern West Virginia, 191532 (Urbana, IL, 1990); Ruiz, Cannery Lives; Kelley, "We Are Not What We Seem': Towards a Black Working-Class Infrapolities in the Twentieth Century South," forthcoming in Journal of American History; Hunter, Contesting the New South. Both Kelley and hunter are particularly adept at drawing the literature on slave resistance to inform studies of resistance by later black wage workers. See also Kelley, Hammer and Hoe: Alabama Communists during the Great Depression (Chapel Hill, 1990), p. 101. See also Mario T. Garcia's fine "Border Proletarians: Mexican-Americans and the International Union of Mine, Mill and Smelter Workers, 1939-1946", in Robert Asher and Charles Stephenson, eds., Labor Divided: Race and Ethnicity in United States Labor Struggles (Albany, NY, 1990) pp. 83-104 and, on slavery, Norrece T. Jones, Jr., Born a Child of Freedom Yet a Slave: Mechanisms of Control and Strategies of Resistance in Antebellum South Carolina (Hanover, NH and London, 1990).

is Morrison, "Afro-American Presence" and Playing in the Dark: Whiteness and the Literary Imagination (Cambridge, MA, 1992); bell hooks, "Representations of Whiteness", in Black Looks: Race and Representation (London, 1992), pp. 165-78 with material from Fusco. 
whiteness in American politics and American culture in his remarkable Rise and Fall of the White Republic. ${ }^{16}$

It would stretch optimism too far to suppose that the study of race, or even of gender, has already established a claim to be central in any revivifying of labor history. Scholarship on race, class, and gender remains in its early stages, and deserves the searching criticism it is sure to receive. The theoretical sophistication of the new scholarship, for example, is at this point far from imposing. New approaches face practical problems in writing and conceptualization which are so daunting as to seem at times insurmountable. Discussing the triad of race, class, and gender would be difficult enough, but that is just the tip of the iceberg. Writing about a single workplace or working-class community might involve analysis of masculine and feminine gender identities formed in concrete material circumstances among workers holding, or developing, or being seen as having, white, African-American, and Chinese "racial" identities. Once we acknowledge that the class identity of, say, an African-American woman worker is influenced not only by her own race and gender identities but also by social relationships with, say, Chinese males (and vice versa), we see the practical difficulties associated with treating race, class, and gender in what Tera Hunter brilliantly terms their "simultaneity"."17

Too often, and here my own work holds out a revealing negative example, authors settle for treating complex identities in manageable dyads, treating white racial identity and class in one work, for example, and leaving class and gender for a later book, or a later section of the book. In addition, when scholarship on white racial identity focuses, as it sometimes must, on the broad political and cultural forces promoting whiteness, it exists in some tension with studies which take day-to-day relations between white and nonwhite workers or the self-activity of African-American workers as their points of departure. Though such tension is potentially exciting and productive, we should not be blind to the threat of a worst-case scenario in which research on white racial identity and male gender identity becomes yet another way to arrogate to white men the center stage in labor history..$^{18}$

${ }^{16}$ DuBois, Black Reconstruction, 700-01; Saxton, The Rise and Fall of the White Republic: Class Politics and Mass Culure in Nineteenth Century America (New York, 1990); see also Eric Lott, "That Seeming Counterfeit: Racial Politics and Early Blackface Minstrelsy", American Quarterly, 43 (June, 1991), pp. 223-54; Lott, Blackface Minstrelsy and the Anerican Working Class, forthcoming; Michael Rogin, "Blackface, White Noise: The Jewish Jazz Singer Finds his Voice," Critical Inquiry, 18 (Spring, 1992); Vron Ware, Beyond the Pale: White Women, Racism and History (New York and London, 1992); Ruth Frankenberg, White Women Race Matters: The Social Construction of Whiteness (Minneapolis, 1993).

"Hunter, in her forthcoming Contesting the New South urges the examination of "gender, race, and class in their simultaneity, in the way that human beings actually experience these social relations".

"See, e.g., the reviews of Wages of Whiteness by Iver Bernstein in Journal of American History, 79 (December, 1992) pp. 120-21; by Joe William Trotter, in Journal of Social 
But as crying as the need is for serious critiques of race, class and gender approaches, labor history has not been well-served by recent dismissive broadsides which verge on branding as fraudulent the entire effort to see class consciousness as part of a set of interpenetrating and historically constructed identities. In a recent article in the prestigious American Quarterly, for example, Steven Watts characterizes race, class, and gender analyses of American history and culture as merely fashionable "incantations". Within labor history, Judith Stein's recent essay on the work of Joe William Trotter and Robin Kelley sets an equally harsh tone. After perceptively noting that Trotter and Kelley pay substantial attention to gender in their studies of race and class, Stein criticizes their emphases on both race and gender as a historical exercises driven by "current political sensibilities". She charges that by imposing categories and judgments from the present onto the past, Kelley and Trotter lose sight of the relations of class power which shaped the lives and consciousness of both black and white workers. Stein does not very much bother to claim, as more venerable Marxist formulations might, that class relations at the base shaped race and gender relations in the superstructure. She ignores the considerable extent to which white male workers themselves raised the issues of race and gender in fashioning a class identity, and assumes that because it supposedly derives from direct experience in production, class is a more timeless category. ${ }^{19}$

Stein's questionable judgment in choosing to single out for criticism two of the most closely documented and deeply historicized books yet produced by historians attentive to issues of race, gender, and class obviously limits the appeal of her critique. Nor is there much possibility for wide embrace of the chaotic combination of wistful populism with hints of a prolier-than-than Marxism which runs through the essays of both Watts and Stein when they argue that consideration of gender and race detracts from the study of class and power. Nonetheless, and especially insofar as they speak as part of the wider attack on multicultural scholarship, Watts and Stein do succeed in framing issues in a way which historians committed to the development of scholarship on race, class, and gender ignore at their peril. The accusations of fashionability and of present-mindedness must in particular be met head on if we are to avoid apologizing for our successes in producing work which is "trendy" in the sense that it grows out of and engages real trends in the recomposition of the labor force and the labor movement in a way that more nostalgic formulations do not. This need not imply a moralistic lecturing of the dead for their failure to

History, 25 (1992), pp. 674-676 and by Lawrence B. Glickman, in The Nation (February 17, 1992), pp. 207-09.

19 Steven Watts, "The Idiocy of American Studies: Poststructuralism, Language and Politics in the Age of Self-Fulfilment", American Quarterly, 43 (December, 1991), p. 653; Stein, "Race and Class Consciousness Revisited", Reviews in American History, 19 (December, 1991), esp. pp. 556-559. 
live up to the current ideals of egalitarianism. The point of historical studies of racial identities in the working class in such groundbreaking books as DuBois' Black Reconstruction and Saxton's Indispensable Enemy has never been to mount a facile indictment of white workers as racist. Rather it has been to understand how historicized racial identities dramatically shaped what workers could do and dream in their lifetimes. In a highly emotional atmosphere, this is a point which is as difficult to make as it is vital. For now, the point is best made in an exploration of concrete examples.

If the proof of the value of the study of the racial identity in labor history lies in its ability to open new dramas within that history, it is appropriate to turn in the balance of this essay to instances which illuminate that ability. While DuBois referred to the epic drama of Reconstruction in making the case for the centrality of race to labor history, I offer three very small dramas, hoping to show in each case how they open out into larger dramas and difficult questions which can invigorate study of the U.S. working class.

Drama One: In the early twentieth century, the great African-American author James Weldon Johnson closely listened to white "engineers, machinists, plumbers, electrical workers and helpers" in a smoking room on a large ship. Their conversations convinced him of "how lean a chance" that the black worker had with "his white brothers of the proletariat." Johnson wrote, "The expression which I heard at least a hundred times was, 'Never let a nigger pick up a tool', 'Never let a nigger pick up a tool'." 20

On one level this is a simple enough vignette providing evidence of working-class racism and of its impact in limiting the economic opportunities of African-American workers and in subverting the prospects for class unity across racial lines. It seems susceptible to a simple explanation, offered by Marxists, by institutionally oriented labor historians and by labor market segmentation theorists alike, which sees white workers' support for racial exclusion as growing out of an economically rational desire to keep African Americans from competing for jobs and from thereby lowering wage rates. ${ }^{21}$ But even when we grant such economic rationality as a factor in exclusion, the repeated rehearsing of the need to exclude within the manly confines of a smoking room is striking. Why, in particular, should skilled workers from trades so successful at practising exclusion have been obsessed so consistently about the need to do so?

Part of the answer lies in the dramatic extent to which the class identity of skilled workers took form around the identification with both whiteness and masculinity. the code of manliness, which david montgomery suggestively placed at the heart of the ethos of late nineteenth and early twentieth-century skilled workers undergirded craft union efforts to main-

20 James Weldon Johnson, Along This Way (New York, 1933), p. 355.

${ }^{21}$ See Saxton, White Republic, pp. 6-7 for acute comments on this score. 
tain and extend autonomy and mutuality. But the ideal was to be not only a man, but a "white man". Those who violated mutuality, and specifically those who broke strikes, not only lacked "any manhood" but "turned nigger". Both African-Americans and women were available as symbols of subservience and of the lack of citizenship rights, and association of one's craft with either women or blacks constituted a threat to manliness. ${ }^{22}$

Whiteness, masculinity and craft pride mingled in the fashioning of an identity among skilled workers. In his autobiography, The Iron Puddler, James J. Davis combined gender and craft in writing of the "man of iron" as a masculine ideal. But Davis added that he wanted "civilization's shock troops grappling with tyrannous nature" to be specially white "men of iron". "Some races are pig-iron; Hottentots and Bushmen are pig-iron. They break at a blow", he added. Others, like the "meek Chinese" let nature slowly "whip [them] with cold, drought, flood, isolation and famine". Only his own race could shoulder the manly work of "belting the world with railroads and bridging the seas with iron boats". The overwhelming resistance to entry of blacks and of females into crafts reflected how widespread was Davis' conflation of craft, race, and gender. Integration at work would not only make the manly.skilled worker associate with the supposedly servile but also would associate his craft with degradation and weakness. Even the material gain to be realized by excluding blacks, Chinese, and others was racialized, and expressed in terms of masculine ideas. As Lawrence Glickman has impressively shown, the workers who defended the "American standard of living", in the industrializing U.S. often put their demands in terms of "white men's wages". In "defining "Americanness" and civilization as against the "other", Glickman adds, such workers "made consumption as much a terrain of exclusion as production had ever been".23

The allegation that blacks threatened the dignity of skilled tradesmen often found expression in workers' language. Not only was "nigger work" generally synonymous with servile, driven labor, but crafts' occupational slang reinforced the point that African-Americans would sully the trades.

2 Mongomery, "Workers' Control of Machine Production in the Nineteenth Century", Labor History, 17 (1976), pp. 491-92; Freifeld, "American Working Classes", pp. 514-22; Goldberg, "Beyond Free Labor", pp. 407-12.

23 James J. Davis, The tron Puddler: My Life in the Rolling Mills and What Came of It (New York, 1922), pp. 72, 108-09 and 158-59; Michael Denning, Mechanic Accents: Dime Novels and Working-Class Culture in America (London and New York, 1987), pp. 175-77; William M. Tuttle, JR., Race Riot: Chicago in the Red Stummer of 1919 (New York, 1984, originally 1970), pp. 142-43. See also Colin J. Davis, ed., Organized Labor in the Twentieth Century South, pp. 113-34, on honor and segregation in the shop crafts. For an academic endorsement of the white craft unions' questioning of African-American manliness, sce John R. Commons, Races and Immigrants in America (New York, 1913), pp. 48-49; Lawrence Glickman, "Inventing the 'American Standard of Living": Gender, Race and Working-Class Identity, 1880-1925", forthcoming in Labor History in Winter, 1993. Glickman takes "white man's wages" from Montgomery, Beyond Equality, p. 254. 
For electrical workers, "nigger" was an impurity fouling connections; for cowboys, a saddlesore was a "nigger brand"; for railroaders, "nigger locals' were burdensome short runs. Workers' language further connected mechanization to "niggers", with the logic built on the twin associations of blacks with the kinds of hard work (such as lifting) which was being replaced by machines and with perceptions that machines and blacks both posed threats to whites' employment. Thus Mississippi sawyers termed devices to turn heavy logs "steam niggers". In many trades powerful winches were "niggerheads". ${ }^{24}$

If shipboard machinists had little immediate reason to fear that AfricanAmericans would take their jobs, they had every reason to think that scientific management and mechanization threatened their manly autonomy. The particular precariousness of the worker at sea's patriarchal authority within his family expressed in concentrated form the more general crises in such authority brought by proletarianization and deskilling. As Joy Parr, Paul Taillon, and Patricia Cooper had demonstrated, such crises could generate a strong commitment to what Parr calls "breadwinner unionism"2s as an expression of both masculinity and class identity. They could also generate fierce assertions of white racial identity which mixed with craft pride in creating an ideal of working-class manliness. In the case of skilled workers, masculinity could not usually be claimed by virtue of doing the hardest and heaviest labor - work that was often left to new immigrants and African-Americans. Therefore masculinity came to be associated ever more closely with craft and discipline and with the avoidance of "nigger work". Indeed the machinists not only tragically saw exclusion of black workers as a critical trade union demand but effected that exclusion precisely through their rituals of brotherhood. ${ }^{26}$

24 The American Thesaurus of Slang, 2nd edn, Lester V. Berrey and Melvin Van Den Bark, eds. (New York, 1962), pp. 724 and 850; A Dictionary of American Slang, Maurice H. Weseen, ed. (New York, 1934), pp. 73 and 82; H.L. Mencken, "Designations for Coloured Folk", American Speech, 19 (October, 1944), p. 169; A.A. Roback, ed., A Dictionary of International Slurs (Elinophaulisms) (Cambridge, MA, 1944), p. 55; for "niggerhead' as a white miners' term for impure, worthless coal, see Trottter, Coal, Class and Color, p. 115; on Mississippi, see McMillen, Dark Journey, p. 157; Dictionary of Americanisms, On Historical Principles [DA], M.M. Mathews, ed. (Chicago, 1951), 2:1117; Roediger, Wages of Whiteness, p. 15.

is Parr, Gender of Breadwinners; Cooper, "Which Workers Built What?" Labor History, 32 (Fall, 1991) pp. 570-72; Taillon, "By Every Tradition and Every Right': Fratemalism and Racism in the Railway Brotherhoods, 1880-1910" (Unpublished paper delivered at the American Studies Association meeting in Baltimore, November, 1991). See also Faue, Suffering and Struggle and Ava Baron, "Questions of Gender: Deskilling and Demasculinization in the U.S. Printing Industry, 1830-1915", Gender and History, 1 (Summer, 1989), pp. 178-99.

26 Taillon, "Fraternalism and Racism"; Foner, Organized Labor and the Black Worker, pp. 103-07; Stuart B. Kaufman and others, eds., The Samuel Gompers Papers: The Early Years of the American Federation of Labor, (Urbana and Chicago, 1987), p. 297 and Paul Taillon, "That Word 'White': Racism and Masculinity in the Debate Over Black Exclusion in the 
Drama Two: In Blood on the Forge, William Attaway's superb 1941 proletarian novel, Big Mat, a black worker in a foundry, knocks out a "hayseed" who is about to hit an Irishman. Mat becomes the "hero of the morning" to the Irish American foundry workers. He wins praise for being both a model "colored worker" and for being somehow more than black. The boss melter in the foundry, a "big Irishman" in charge of five furnaces, marvels: "Never had a colored helper work better on the hearth [ ... ] do everythin' the melter tell him to do and take care of the work of the whole crew if he ain't held back." Other Irishmen on the gang give Mat the title "Black Irish". One allows that "lots of black fellas have Irish guts". Another adds, "The black fella make a whole lot better Irisher than a hunky [Hungarian] or ginny [Italian] "Big Mat does not stay around after work to celebrate his new-found acceptance and his new "race". Instead he finds refuge in the "pleasant thought" of animals "tearing at each other" and hurries off to watch the dogfights. ${ }^{7}$

Perhaps no single passage from a source on labor's past provides quite so exciting a set of reminders of how much historians still have to learn about issues of both power and identity within the American working class. Mat's situation is fraught with both drama and peril. To the boss melter, he seems the very essence of manliness. This masculinity is what underlies his ability to transcend race in a partial way. As the hardest worker and a tough fighter, Mat wins praise and keeps a job. The Irish skilled workers and petty bosses - the line was by no means clear in many workplaces in the industrializing U.S. - accept him not only as an American but as almost an "Irisher". However, the very behaviour which establishes him as manly and American before the Irish on a gang sets Mat apart as an unmanly laborer willing to "work like a nigger' to curry favor from the boss melter, when seen from the point of view of the "hayseed", and "hunky" and the "ginny". We know all too little about the crosscurrents of race and masculinity which black workers navigated in getting and keeping places on work gangs and occasionally in managing to learn a skilled trade from white workers. We have not examined the ways in which everyday life at work reinforced and forged broader cultural images of the AfricanAmerican male as either supermasculine or docile by requiring that he act both parts.

Nor do we know how manliness and race interacted in instances of biracial mobilizations by labor. Brotherhood of Timber Workers (BTW) organizers disarmed racism in Louisana and Texas just before World War I by arguing that "negro" and white "MEN" joined the union while "nigger [and] white trash company suckers" broke strikes, for example.

International Association of Machinists, 1888-1895" (unpublished paper delivered to the North American Labor History Conference at Wayne State University, 1990). On "nigger work", see Roediger, Wages of Whiteness, pp. 144-45 and 180. On physical labor, masculinity and class see Paul Willis, "Shop Floor Culture Masculinity and the Wage Form", in John Clarke, Chas Crichter and Richard Johnson, eds., Working Class Culture: Studies in History and Theory (New York, 1979), pp. 185-98.

27 Attaway, Blood on the Forge (New York, 1987, originally 1941), pp. 122-23. 
Historians have rightly praised their successes as exemplary reflections of the partial triumph of a common ciass identity over racial division. ${ }^{28}$ But we have been slow to see how fully the questioning of racism by white male workers has rested in such instances on appeals to common manliness. $^{29}$ The appeal to values defined as masculine (and even to heterosexism) by the BTW brilliantly reversed the fear that white manliness (and arguably heterosexuality) might be breached - a fear which runs through the obsessive repetition of a line like "Never let a nigger pick up a tool." But we are far from knowing the full dynamics of, or the limits to, historical attempts to build a manly antiracism.

Terms like "black Irish" and "ginny" signal a still more complex set of dramas. Although the supposedly clear distinction between whites and nonwhites underlies racial ideology in the U.S., the history of immigration has constantly mocked that distinction. the use of "black Irish" to register high regard for Mat by the Irish workers suggests the possibility that ethnic Americans at times saw race differently than did the larger U.S. culture. The term "ginny" derived from Guinea, a region of West Africa from which slaves were exported. Its application to dark-skinned Italians reminds us that immigrants later categorized as whites often were originally the objects of debate where racial identity was concerned. Referring to the early twentieth-century U.S., the historian of immigration John Higham has observed: "In all sections native-born and northern European laborers called themselves 'white men' to distinguish themselves from the Southern Europeans whom they worked beside."30 Immigrant workers were therefore often what John Bukowczyk has perceptively called "notyet-white ethnics" in the double sense that they were still learning (or challenging) the ways of whiteness and still seeing their own whiteness questioned..$^{31}$

Although one of the strongest suits of recent labor history has been its ability to illuminate how immigrant workers constructed their own senses

28 Green, "Brotherhood", is a superb early study which emphasizes class unity in the BTW. For a much cruder version, see my "An Injury to One: IWW Organizing in the Deep South", Industrial Worker, 659 April, 1988), p. 5. Eric Amesen's Waterfront Workers is probably the best study of race and the labor process in one industry and place, and his current broader project, on black workers, promises to add a great deal to our knowledge in this regard.

29 For a lengthy attempt to address these, questions, see my "Labor, Gender and the 'Smothering' of Race: Covington Hall and the Complexities of Class", in David Roediger, Up from Whireness: Essays on Class and Race, Past and Present (forthcoming from Verso, 1993).

${ }^{30}$ Higham, Strangers in the Land: Patterns of American Nativism, 1860-1925 (New York, 1963), pp. 173 and 66. On guinea, see Donald Tricarico, "Guido: Fashioning an ItalianAmerican Youth Style", Joumal of Ethic Studies, 19 (Spring, 1991), esp. pp. 56-57 and Frederic G. Cassidy and Joan Houston Hall, eds., Dictionary of American Regional English, Volume 2 (Cambridge, MA and London, 1991), p. 838.

31 Bukowczyk, as cited in Barry Goldberg, "Historical Reflections on Transnationalism, Race, and the American Immigrant Saga' (unpublished paper delivered at the Rethinking 
of ethnicity and Americanity, ${ }^{32}$ we know very little about the history of the not-yet-white ethnic worker and of how the not-yet-white ethnic became white. The legal requirement, from 1790 until well into the twentieth century, that an immigrant be "white" in order to be naturalized and the welter of consequent litigation which fully lay bare the biological fictiveness of race, have scarcely been noticed by labor historians. ${ }^{33}$ The historical tensions between choosing to identify oneself as white or as an Irish American (fully present in the passage on Big Mat) have not seemed problematic to researchers used to seeing "white ethnic" as a natural category. The prehistory of the racial identity of "white" immigrant workers, in attitudes toward gypsies, travellers, Jews, Africans, and others in specific European peasantries and working classes is unexplored territory. The processes by which less recently arrived immigrants taught racism (and, I would add, white racial identity) to the more recently arrived have only recently been prominently identified as subjects for historical research in James Barrett's fine essay on "Americanization from the bottom up". Most importantly, historians lack the sense of drama and the appreciation of immigrant working-class self-activity which runs through the great novelist James Baldwin's seminal work "On Being 'White' [ . . . ] and Other Lies". In holding that immigrants "became white [ . . . ] by deciding they were white" over time, Baldwin unearths a vital historical process which not only took place largely in workplaces and working-class communities but which also shaped those workplaces and communities. ${ }^{34}$

Migration, Race, Ethnicity and Nationalism in Historical Perspective Conference at the New York Academy of Sciences, May 1990).

${ }^{32}$ Leading recent examples include David Emmons, The Butte Irish: Class and Ethnicity in an American Mining Town (Urbana, 1989); James R. Barrett, "Americanization from the Bottom Up: Immigration and the Remaking of the Working Class in the United States, 18801930", Journal of American History, 79 (December, 1992), pp. 996-1020; Cohen, Making a New Deal; Gary Gerstle, Working-Class Americanism: The Politics of Labor in a Textile City, 1914-1960 (Cambridge, MA, 1989) and Donna Gabaccia, Militants and Migrants: Rural Sicilians Become American Workers (New Brunswick, NJ, 1988). Studies which begin to address the formation of white identity among immigrant groups include Roediger, Wages of Whiteness, pp. 133-63; Dale T. Knobel, Paddy and the Republic: Ethnicity and Nationality in Antebellum America (Middletown, CT, 1986), pp. 82-99 and esp. Robert Orsi, "The Religious Boundaries of an In between People: Street Feste and the Problem of the Dark* Skinned Other in Italian Harlem, 1920-1990", American Quarterly, 44 (September, 1992).

${ }^{33}$ Stanford Lyman, "The Race Question and Liberalism", International Joumal of Politics, Culture and Society, 5 (Winter, 1991), pp. 203-25; Joan M. Jensen, Passage from India: Asian Indian Immigrants in North America (New Haven and London, 1988), pp. 246-69.

34 Barrett, "Americanization from the Bottom Up", 1001-002; Baldwin, "On Being 'White' ... And Other Lies," Essence (April, 1984), pp. 90 and 92. Noel Ignatiev's excellent "Whiteness' and American Character", Konch, 1 (Winter, 1990), pp. 36-39 alerted me to Baldwin's article. For useful comments on historicizing "white ethnic" consciousness, see Barry Goldberg and Colin Greer, "American Visions, Ethnic Dreams" in Louis Kushnick, ed., Sage Race Relations Abstracts, 15 (1990), pp. 29-31. My own unpublished paper "Whiteness and Ethnicity in the History of 'White Ethnies' in the United States' explores the same issue. Its conclusions will appear in David Roediger, Shades of Pale: American Whiteness in the Last Century (forthcoming from Free Press, 1995). 
Drama Three: My great aunt, who recently died at 83, worked much of her life as a telephone operator in the North - South border city of Cairo, Illinois. Assertive, fun-loving and a staunch trade unionist, she exemplified much of the classconsciousness, independence, and willingness to challenge convention of an earlier generation of telephone operators well-described in Steven Norwood's Labor's Flaming Youth. ${ }^{35}$ Through most of her working life, she in turn employed part-time an African-American domestic worker to whom she related paternalistically in every sense of the word. If her job immersed her in working-class women's culture, her status as an employer of black labor identified her with respectability and with the "better class of people" in Cairo. She fiercely opposed integrating the ranks of telephone operators, drawing on arguments in which whiteness and class defined each other.

Being served, if only for ten hours per week, by a nonwhite woman, influenced my great aunt's daily life, her racial attitudes and her class identity. But little in the historical literature on either labor or women's history helps us to understand how. Although there is abundant evidence suggesting that white working-class families hired black and Mexican American servants, especially in the South and Southwest during the early twentieth century, Tera Hunter is practically alone in making this employment relationship a focus of her historical research. As Hunter keenly observes, the availability of nonwhite servants way a key to both the domestic economy and the political economy of cotton mill villages in the South. Mills gained "progressive" images as havens for white workers by barring African Americans from textile jobs. They paid whites so poorly that whole families had to work, leaving little time for women and children to perform traditional domestic tasks. But since African-Americans could be hired so cheaply, white mill workers could have black servants. Indeed, some gave the "necessity" of having servants as a reason for accepting wage work. ${ }^{36}$

The expectation by workers of service from nonwhite workers was far from confirmed to domestic labor. The rituals of white working-class manliness, performed at sites as various as barber shops, bars, and brothels, often included service by African-American workers. Eric Arnesen's recent research on the railroad trades suggests that some white engineers

3s Norwood, Labor's Flaming Youth: Telephone Operators and Worker Militancy, 1878-1923 (Urbana and Chieago, 1990).

${ }^{36}$ Hunter, Contesting the New South, forthcoming; David Katzman, Seven Days a Week: Women and Domestic Service in Industrializing America (New York, 1978); Janiewski, Sisterhood Denied, pp. 43-44 and 127-29; Victoria Byerly, Hard Times Cotton Mill Girls: Personal Histories of Womanhood and Poverty in the South (Ithaca, NY, 1986), pp. 99, 125, 147 and 152; Carter G. Woodson, "The Negro Washerwoman: A Vanishing Figure", Journal of Negro History, 15 (July, 1930), p. 271; Trotter, Coal, Class and Color, p. 91; LeeAnn Whites, "The DeGraffenreid Contoversy: Class, Race and Gender in the New South", Journal of Southern History, 54 (August, 1988), pp. 477-78 n.82; H. Roger Grant, ed., Brownie the Boomer: The Life of Charles B. Brown, An American Railroader (DeKalb, IL, 1991), pp. 138-39. 
preferred black helpers because forms of personal service (and dangerous work) could be exacted from them but not from whites. Thomas Sugrue's fascinating study of the "slave market" through which unionized white construction workers essentially acted as subcontractors employing African-American casual laborers in post-World War II Detroit adds a further reminder that the material benefits of whiteness were not always confined to advantages in terms of labor competition. ${ }^{37}$

In none of these instances can a quick and easy formula be invoked to summarize the impact of buying services from nonwhites on the racial, gender, or class identities of white workers. Mill families, for example, appear to have given up claims to middle-class status by sending their children out to work and using the wages derived to hire African-American servants. ${ }^{38}$ My great aunt, childless and widowed after a short marriage, approached middle class status and identity in large part because she employed black labor. But whatever the significant variations, for the minority of white workers who hired nonwhites there was no class identity which was not also at once a racial identity.

Much the same can be said for the majority of the white working class which did not hire nonwhite labor. In a recent and provocative essay arguing for "bringing the unions back in" as a key to the future of labor history in the U.S., Howard Kimeldorf maintains that an approach which takes "the job" or "working class culture" as a starting point "holds out the attraction of advancing beyond the narrow 'male and pale' focus of the old union-centred history, but it does so while retreating from the larger questions of social transformation that drew earlier generations of labor historians to the study of unionism in the first place". ${ }^{39}$ My own view is that the tactical decision of whether to begin studies with the shopfloor, the union hall or the tavern as a focus is far less important today than the decision to engage fully the interplay of race, gender, and class. Failing that, we will not only miss much in the histories of those workers who were not white men but will also misapprehend the consciousness of those for whom maleness and paleness shaped class identity. By probing small

${ }^{3}$ I am indebted to Eric Arnesen for sharing his parts of his forthcoming study of black railway workers for the point on engineers. On Detroit, see Sugrue, "The 'Slave Market' and Casual Labor in Postway Detroit' (unpublished paper delivered to North American Labor History Conference, Wayne State University, October, 1992).

Hunter, Contesting the New South, forthcoming.

39 Howard Kimeldorf, "Bringing Unions Back In: Or Why We Need a New, Old Labor History", 32 (Winter, 1991), pp. 102-103. Cf. Nell Irvin Painter, "One of Two Things About The Fall of the House Labor," Labor History, 30 (Winter, 1989), pp. 118-121. The study of racial identity, so proloundly a political as well as a cultural phenomenon, is bound to challenge fundamentally the tendency of labor historians to separate "culture' from (trade union and electoral) politics. See Geoff Eley, "Labor History, Social History, Alltagsgeschic. the: Experience, Culture, and the Politics of the Everyday - A New Direction for German Social History?" Journal of Modem History, 36 (1991), 249-260 for insightful commentary on the tendency to separate cultural and organizational matters in working-class history. 
dramas such as those described by James Weldon Johnson and William Attaway, and lived by my great aunt, we may position ourselves to produce eventually a synthesis which makes the role of the whole working class central to the drama of U.S. history.

As the only nation to experience significant formation of a waged working class while a large-scale system of racial slavery continued to prevail within its borders, the U.S. has clearly had a distinctive history where race and labor are concerned. But in pursuing the study of race, U.S. labor historians will not be taking an utterly exceptional course. Racial divisions and racial dynamics within the working class have, of course, become sharply posed issues for historians of recent European labor, but, as the exemplary work of Peter Linebaugh and others have shown, race and slavery also played significant earlier roles in shaping class consciousness and lives or workers in some European port cities. The intimate connections between the slave trade and the rise of capitalism ensured that even in cities with few black workers, maritime workers in the eighteenth and early nineteenth century were well situated to compare their labor and conditions at sea with those of slaves. ${ }^{40}$ If the question of how the employing of nonwhite servants shaped class consciousness and gender relations among white workers is an interesting one in the U.S. context, it is a vital one in the South African context. Beyond this, and realizing that race is a social construction rather than a biological fact, we need to ask whether some tensions among so called "whites" were in fact cast as racial divisions. Richard Williams has recently and forcefully suggested that anti-Irish discrimination in Britain, for example, is best seen as a variety of racism rather than of ethnic prejudice. The questions of whether and when anti-immigrant, anti-minority and pro-imperialist ideas and state-sponsored racism created "white" identity among European workers remain open ones. ${ }^{41}$ They are far more likely to be sharply posed and aptly answered if U.S. labor historians fully rethink the drama of race and class.

"See, especially, Peter Linebaugh, "What If C.L.R. James Had Met E.P. Thompson in 17927" in Paul Buhle, ed., C.L.R. James: His Life and Work (London and New York, 1986), pp. 212-19 and The London Hanged: Crime and Civil Society in the Eighteenth Century (London, 1991), esp. p. 349; Peter Fryer, The History of Black People in Britain (London, 1984). Perhaps the finest history of race and labor in an Atlantic economy is Walter Rodney, A History of Guyanese Working People, 1881-1905 (Baltimore and London, 1981). See also Peter Fryer, Staying Power: The History of Black People in Britain (London, 1989).

il Richard Williams, Hierarchical Structures and Social Value: The Creation of Black and Irish Identities in the United States (New York, 1990), esp. p. 2. See also Orsi, "Inbetween People", p. 315 and Robbic McVeigh, "The Specificity of Irish Racism", Race and Class, 33 (April-June, 1992), pp. 40-43; Clive Harris, "Configurations of Racism: the Civil Service, 1945-1960", Race and Class, 33 (July -September, 1991), pp. 1-30; Joseph Bristow, Empire Boys: Adventures in a Man's World (London, 1991); Annie Phizacklea, Unpacking the Fashion Indusiry: Gender, Race and Class in Production (New York, 1990). 